\title{
«ХРАМУ МЕЛЬПОМЕНИ» 150 РОКІВ
}

Статтю присвячено 150-річчю (2017) з часу заснування у м. Кропивницькому Зимового міського театру інженера Г.В. Трамбицького (нині Кіровоградського музично-драматичного театру ім. М. Л. Кропивнищького (1865-1867 рр.).

Ключові слова: Слисаветград, Кіровоград, театр, Г. В. Трамбиџький, М. Л. Кропивницький, «Храм Мельпомени».

Статья посвящена 150-летию (2017) со времени основания в г. Кропивницком Зимнего городского театра инженера Г. В. Трамбиикого (ныне Кировоградского музыкально-драматического театра им. М. Л. Кропивницкого (1865-1867 г2.).

Ключевые слова: Елисаветград, Кировоград, театр, Г. В. Трамбицкий, М. Л. Кропивницкий, «Храм Мельпоменьр».

The article is dedicated in 2017150 years a case of foundation of Zymoviy public theater by engineer G. Trambytskiy in Yelisavetgrad (Kirovograd music and drama theatre by M. Kropivnytskyi now) (1865-1867).

Key words: Yelisavetgrad, Kirovograd, theater, G. Trambytskyi, M. Kropivnytskyi, temple of Melpomene.

Міський (Зимовий) театр у Кропивницькому по вулиці Дворцова, 4 (Музично-драматичний театр імені М. Л. Кропивницького) - блискучий зразок архітектури пізнього класицизму з елементами стилю ампір, який до цього часу залишається майже недослідженим, а його автор проекту i будівничий інженер Г.В.Трамбицький майже невідомим. Архітектура - об'ємно-планувальна побудова і стильове трактування будівлі міського театру - єтиповою для другої половини XIX ст.

У 1860-1870-ті роки по всій Європі широко розгорнулося будівництво театральних споруд. Театри будувалися не лише у великих, а й у провінціальних містах тодішньої Росії. «Только в провинции любили театр по-настоящему. Преувеличенно, трогательно, почти самоотверженно и до настоящего восторженного одурения» [7, 91]. Одна 3 перших чудових театральних споруд Південної Росії була зведена майже 150 років тому у м. Слизаветграді Херсонської губернії (з 1934 р. - м. Кіровоград, 314 липня 2016 р. - м. Кропивницький).

Будівля стаціонарного театру в Єлизаветграді була збудована у 1865-1867 pp. за проектом і на власні кошти місцевого інженера Г. В. Трамбицького.

Георгій Васильович Трамбицький (18151884 рр.) інженер, генерал-майор, у 1867 році будучи ще полковником, збудував театр у Слиза- ветграді за свій кошт. Один з його синів, Олексій (10.02.1860-1918 рр.), також був архітектором. 3 1887 р. - академік архітектури, викладав у Академії Мистецтв у Петербурзі, став іiі ректором та одружився на Марії Кракау, дочці відомого архітектора на той час. Під час будівництва Георгієм театру у Єлизаветграді, його синові Олексію доручили утримання імператорських театрів, у тому числі Маріїнського театру опери $[7,90]$. На зламі XIX-XX ст. працював у Полтаві, де за його проектом збудовано Народну аудиторію в пам'ять М. Гоголя (1898-1901р.) [10, 375]. Брат Георгія Віктор Васильович (1895-1917 pp.) був композитором, автором декількох опер [7, 90].

До відкриття Міського постійного театру інженера Г.В. Трамбицького у м. Слизаветграді театральні вистави влаштовувались заїжджими гастролерами в тимчасово збудованих чи дерев'яних балаганах. Перші такі театральні вистави у місті виникли у 1830 р. У згаданому тимчасовому театрі давала вистави харківська трупа Штейна, а згодом Жураховського [7, 94]. Деякий час у місті діяв збудований у 1840-х рр. купцем Плотниковим великий за розмірами дерев'яний театр $[3,84]$. Але на початку 1850 року він згорів ущент разом 3 усім театральним реквізитом і майном $[1,60 ; 7$, 97]. Після цього «єлизаветградські театрали» збирались у великій залі палацу купця Дружині- 
на. Для театральних вистав використовували також манеж (з дозволу військових) [1, 60].

Нарешті, у 1865 році місцевий інженер-полковник Г. Трамбицький придбав у міському управлінні ділянку землі на початку Дворцової вулиці, на якій і збудував Міський постійний театр. Офіційне відкриття першого Міського, згодом так званого Зимового театру, відбулося у 1867 році через два роки від початку будівництва $[9,33]$.

Це була «розкішна класична споруда із сучасною сценою і глядацькою залою, яка не поступалася навіть столичним театрам» $[4,542]$. Театр не лише зовні, а й усередині відповідав і духу часу, й духу мистецтва.

Опубліковані спогади видатного уродженця міста Дона Амінадо (Амінодав Петрович Шполянський, поет-сатирик, мемуарист, 1888-1957 рр.), завдяки яким маємо змогу уявити цю будівлю Міського театру Г.В. Трамбицького у Єлизаветграді в перший період його початкової діяльності до початку XX ст.:

«... Театр был выкрашен в ярко розовый цвет, на фронтоне золотыми буквами так и было начертано: Храм Мельпомены <..> .Четыре колонны поддерживают фронтон: направо - вход для публики, с левой стороны - святая святых: вход для артистов...

Внутри театра $<\ldots>$ и вестибюль, и длинное фойе, и у каждого внутреннего входа в зал непроницаемые контролёры... И, наконец, сам зал. Боже, с каким трепетом входили мы в Храм искусства!

$<\ldots>$ Всё в этом несомненном храме было ловко и тонко обдумано. И знаменитая, спускавшаяся с потолка люстра в лирах и ажурах; и вышка раек - галёрка с широковещательными надписями на каждом столбе...

$<\ldots>$ Первый, второй, третий звонок <..> следовали с короткими промежутками, один за другим. Лампочки, под молочными абажурами, угасали: зал стыдливо откашливался и постепенно стихал; равномерно колыхавшийся тяжёлый занавес медленно поднимался вверх; и веял ветер театральный, как говорил поэт, и мистерия начиналась» $[1,61]$.

Таким чином, це був характерний ярусний театр, в якому театральний простір побудований за аналогією до європейських театрів з урахуванням усіх оптичних і акустичних вимог.

Перша вистава у новому стаціонарному театрі була дана у день відкриття його 1867 року трупою Виходцева, яка прибула до Слизаветграда на Георгї̈вський ярмарок [7, 97].
Але найбільшої слави Слизаветградський драматичний театр набув, коли «В цьому будинку в жовтні 1882 року під керівництвом великого артиста і драматурга М. Л. Кропивницького відбувся перший виступ українського професійного театру», до складу якого ввійшли І. Тобілевич (Карпенко-Карий), М. Садовський (М. Тобілевич), М. Заньковецька, М. Старицький, П. Саксаганський (П. Тобілевич) [2, 540]. Нині перед академічним музично-драматичним театром імені М.Л. Кропивницького височить гранітна вертикальна стела - пам'ятник драматургові та актору Маркові Лукичу Кропивницькому (1840-1910рр.) 1968 р. (Скульптор Е. Кунцевич. Висота стели 2,5 м) $[6,259]$.

Місто мало ще один театр - за взірцем театру Трамбицького - двоповерховий, прямокутний в плані, так званий театр Кузмицького $[5,51]$. Проте Міський театр інженера Г. В. Трамбицького домінував своїм архітектурно-будівельним пошуком та яскраво-рожевим фасадом.

Невелика кількість іконографії - листівок та фотографій цієї споруди кінця XIX-початку XX ст. з фондів ЦДКФФАУ, НБУВ, МТМКУ, ДІБУ та ДНАББ - відтворює цілісний образ єдиної будівлі Міського театру в Кропивницькому останньої чверті XIX - початку XX ст.

Міський театр Г. В. Трамбицького в Слизаветграді являв собою самостійний замкнутий об'єм, який посідав важливе місце в композиції Дворцової вулиці - центральної вулиці міста. Перед ним розміщувалася широка еспланада.

Стилістична належність першої будівлі належить до ідейного й художнього напряму в архітектурі пізнього класицизму з елементами стилю ампір. Тут і вузькі вертикальні вікна, які завершувались півциркульними арками без обрамлення, i криволінійної форми декоровані фронтон і аттик, і ажурні металеві орнаменти в огородженні балкона головного фасаду.

Основу композиції наступного проекту становить єдина симетрична композиція - двоповерховий прямокутний об'єм, перекритий двоскатним дахом, $з$ піднятою сценічною коробкою 3 люкарнами, але окремі його елементи - суцільні вертикальні вікна, невеликий чотириколонний портик тосканського ордеру перед входом до будинку, завершений балконом, який прикрашено декоративними вазами, - створюють неповторний театральний вигляд будівлі.

Головним акцентом фасаду впродовж всього існування театру — плавний криволінійної форми фронтон — надає виразної декоративності будівлі. 
На початку XX ст. завершували фронтон «Зимового театру» скульптурна композиція з трьох із дев'яти муз давньогрецької міфології, а саме: центральна фігура - статуя Мельпомени - муза трагедії; друга фігура ліворуч - Талія — муза танців і третя фігура праворуч - Терпсіхора - муза комедії та прикрашений барельєфною декорацією «Ліра» тимпан фронтону; на аттику над карнизом фасадної композиції - характерні елементи перехідного стилю від ампіру до неоромантизму (див. іл.). Отже, декоративні мотиви відбились у елементах його скульптурного декору, що характерно для стилю неоромантизму другої половини XIX ст.

Але «всяк стоящий перед этим зданием должен не только присмотреться к его архитектуре, рассмотреть фронтон, $<\ldots>$ но и обязательно посмотреть себе под ноги, чтобы увидеть еще одну достопримечательность этого города - каменную мостовую перед театром, выложенную в манере “а-ля павлинье перо" в 1889 году. Она и сейчас изумляет изяществом, простотой и аккуратностью исполнения повторяющегося рисунка <...>» $[7,96]$.

Таким чином, прямокутний монументальний об'єм будівлі з піднятою сценічною коробкою над двосхилим дахом, строга симетрична композиція, кожна зі сторін споруди має два фланкуючих ризаліти навколо втопленого головного фасаду, центральна вісь якого вирішена у вигляді портика 3 чотирма тосканськими колонами, за яким - головні входи в глядацьку залу, гострокінцеві декоративні башточки на кутових частинах будівлі, декоративні вази-акротерії на аттиках головного фасаду, - всі ці скульптурні прикраси зовні надали споруді Міського театру інженера Г. В. Трамбицького в Слизаветграді театральний своєрідний дух тої епохи.

У 1917-1919 році театральне життя в Єлисаветграді практично згасло: професійні актори, здебільшого, емігрували або ж залишили сцену, а «розкішне приміщення» Міського театру інженеpa Г. В. Трамбицького після його націоналізації у 1920 році віддали різним установам та організаціям, а також аматорам і заїжджим трупам.

Однак у 1939-1941 pp. за рішенням уряду Радянської України в тодішній Кіровоград направили з Москви професійну акторську трупу 3 пересувних московських театрів і оголосили iї театром російської драми ім. С. М. Кірова, який і розмістився в Міському театрі інженера Г. В. Трамбицького $[4,541]$. Театр російської драми існував у Кіровограді до початку Другої світової війни, але під час посиленої евакуації московські актори залишили місто і практично трупа драмтеатру розпалася. Новий етап діяльності Театру ім. С. М. Кірова відноситься до 1944 р. За наказом Комітету у справах мистецтв України від 30 листопада 1944 року відтворений російський драмтеатр розмістився в іншому приміщенні колишнього будинку Громадського зібрання по вулиці Леніна (колишня Дворцова), 22. А споруда Міського театру інженера Г.В. Трамбицього була передана Кіровоградському обласному державному українському музично-драматичному театру ім. М. Л. Кропивницького, заснованому на базі реорганізованого Олександрійського українського музично-драматичного театру. Почав працювати в червні 1944 року після реевакуації 3 м. Красноводська Туркменської РСР. Тоді ж вийшов наказ Управління у справах мистецтва про присвоєння театру імені М. Л. Кропивницького [13].

У 1947-1948 pp. в Обласному відділі «Облсільпроекту» у справах архітектури Кіровоградської області було оголошено про перший конкурс на розробку проекту реконструкції театру «Російської драми» в Кіровограді. Конкурс на ескізний проект реконструкції театру Російської драми був проведений на початку 1947 р. В конкурсі брали участь небагато фахівців. Премію отримала група спеціалістів у складі архітектора Маслова (?), інженера Калініченка (?). та художника Головіна (?). Проведення конкурсів Управлінням по справах Архітектури були доведені до проектних організацій, але внаслідок невеликої наявності архітектурних кадрів в області в тих конкурсах участі ніхто не брав [11, арк. 14].

У 1950 році Виконком Кіровоградської області провів перші роботи з ремонту приміщень Кіровоградського театру російської драми за рахунок коштів у сумі 65 тисяч крб. 3 місцевого бюджету області [12, арк. 110].

Проте 25 вересня 1959 року Рада Міністрів УРСР приймає постанову про ліквідацію Кіровоградського державного російського драматичного театру ім. С. М. Кірова 3 переведенням його до міста Жданова (тепер Маріуполь), який за новим статусом отримує чинну назву «Донецький обласний російський драматичний театр у Маріуполі». Майно колишнього ліквідованого театру ім. Кірова було передано театрові ім. М. Л. Кропивницького [4, 544].

Таким чином, $\mathrm{XX}$ ст. внесло суттєві зміни у зовнішній вигляд та інтер'єри будівлі. Внаслідок численних реконструкцій у 1908-му та 1911 pp. (скульптурна композиція «Храму Мельпомени»), особливо невдалих реставрацій у радянський час 
у 1927-му, 1954-1958 рр. (бокові прибудови на всю висоту будівлі), 1975-1976 рр. будівля театру повністю втратила первісні інтер'єри, була спотворена прибудовами первісна композиція іiі фасадів [1, 60-61]. Нині театр поєднує еклектизм архітектури радянського періоду 3 історичними формами періоду неоромантизму.

У 2000 році будівлю Кіровоградського музично-драматичного театру імені Марка Кропивницького в Кіровограді визнано «аварійно-небезпечною».

У 2002 році поновлені ремонтні роботи приміщень, в результаті проведених робіт будівля театру - пам'ятка архітектури другої половини XIX ст. була «частково зруйнована». У 2004 році завдяки фінансуванню 3 державного бюджету, розпочалася реконструкція театру. У березні 2005 року до Міжнародного дня театру (27 березня) мав завершитися iĭ перший етап. Поетапне виконання ремонту дало змогу театральним діячам продовжувати роботу. Проводити репетиції в період відновлення репетиційної зали доводилось навіть у буфеті. Саме в буфеті й була підготовлена прем'єра сезону 2005 р. «Моя прекрасна леді». Але колектив театру чекав того часу, коли «театр для своїх служителів та глядачів стане затишним, теплим місцем» [14].

У 2009 році будівля театру опинилася у надзвичайно аварійному стані [15]. Капітальний ремонт і реконструкція театру проводилися впродовж декількох років, під час виконання яких було освоєно близько 4-х мільйонів гривень. Самі роботи велися поетапно - 3 виділенням на них 1,5 мільйона гривень щорічно [16], а сама професійна робота Музично-драматичного театру ім. М. Л. Кропивницького була призупинена.

У самому Кіровограді для театру ім. М. Кропивницького немає інших сценічних майданчиків. Проте будівлю нового міського Музично-драматичного театру на 1000 місць, яка зводилася для нього у 1979 році за проектом співробітників Діпроміста - архітекторів Ю.Ф. Худякова, О. В. Ладної, інженера Л. Г. Сандлера $[8,28]$, тепер переобладнано під торговий центр. Не залишилось у місті жодного Будинку культури, на сцені якого міг би «перебиватися» театр під час ремонтно-відновлювальних робіт головної будівлі театру.

Нарешті у 2012-2013 pр. було проведено відбудову і реставрацію приміщень Кіровоградського музично-драматичного театру ім. М.Л.ККопивницького і колектив театру відновив свою театральну діяльність.
Таким чином, Музично-драматичний театр імені М.Л.Кропивницького у нинішньому м. Кропивницькому являє собою пам'ятку історії та культури (Охорон. № 10), архітектура якої має відбиток культурного розвитку своєї епохи від стилю ампір до романтичних декоративних тенденцій неоромантизму другої половини XIX ст.

\section{Умовні скорочення}

ЦДКФФАУ - Центральний державний кіно-, фото-, фонодокументів України імені Г.С. Пшеничного

НБУВ - Національна бібліотека України імені В. І. Вернадського

НІБУ - Національна історична бібліотека України

ДНАББ - Державна наукова архітектурно-будівельна бібліотека імені В. Г. Заболотного

МТМКУ - Музей театрального, музичного та кіномистецтва України

\section{Джерела та література}

1. Босько В. Храм Мельпомени. // Історичний календар Кіровоградщини на 2007 рік / Люди. Події. Факти. - Кіровоград : Полімед-Сервіс, 2006.

2. Бракер Н. До історії українського театру на Єлисаветградщині / Н. Бракер // Кіровоградщина. Історія. Традиції, Сучасність ; за загальною редакцією О. В. Чуднова. Кіровоград, Імекс-ЛТД, 2008.

3. Історія міст і сіл УРСР. Кіровоградська область ; редкол. тому Сиволап Д. С. (голов. ред.), Безтака П. М., Вогульський А. А. та ін. - К. : голов. ред. УРЕ,АН УРСР, 1972. - 816 c.

4. Матівос Ю. Драматична доля драматичного / Ю. Матівос // Кіровоградщина. Історія. Традиції. Сучасність ; за заг. редакцією О. В. Чуднова. - Кіровоград : Імекс-ЛТД, 2008. - $640 \mathrm{c}$.

5. На память о родном крае // История Центральной Украины / сост. А. Чуднов. - Кировоград : Имекс-ЛТД, 2008. - $432 \mathrm{c}$.

6. Памятники истории и культуры Украинской ССР // Каталог-справочник / П. Т. Тронько [и др.] ; АН УССР. — К. : Наукова думка, 1987. - 736 с.

7. Петраков В.В.Елисаветград в старой открытке // «Маленький Париж» / В.Петраков. - М. : Пинакотека, 2004. - 240 c.

8. Театр в Кировограде // Строительство и архитектура. 1979. — № 1.

9. Театр Марка Кропивницького // Минуле і сучасне. Альбом. Автор-упорядник В.П. Шурапов. - Кіровоград : ПВЦ «Мавік», 2004.

10. Тимофієнко В. В. Зодчі України кінця XIII - початку XX століть // Біографічний довідник / Володимир Тимофієнко. - К. : НДІТІАМ, 1999. - 476 с.

11. ЦДАВОВУУ. - Ф. 4906. - Оп. 1. - Спр. 1351.

12. Там само. - Ф. 2. - Оп. 8.- Спр. 203.

13. ДАКО. - Ф. Р-6707.-- Од. зб. 53, 1838-1950 pp. - Кіровоградський обласний державний архів // Путівник. Кіровоград, 1966.

14. Інтернет-ресурс від 16 березня 2005 р.

15. Інтернет-ресурс від 23 квітня 2009 p.

16. Інтернет-ресурс від 24 листопада 2009 p.: www.informer.ua. 


\section{References}

1. Bosko, V. Khram Melpomeny. // Istorychnyi kalendar Kirovohradshchyny na 2007 rik / Liudy. Podii. Fakty. Kirovohrad : Polimed-Servis, 2006.

2. Braker, N.Do istorii ukrainskoho teatru na Yelysavethradshchyni / N. Braker // Kirovohradshchyna. Istoriia. Tradytsii, Suchasnist ; za zahalnoiu redaktsiieiu O. V.Chudnova. -Kirovohrad, Imeks-LTD, 2008.

3. Istoriia mist $\mathrm{i}$ sil URSR. Kirovohradska oblast ; redkol. tomu Syvolap D. S. (holov. red.), Beztaka P. M., Vohulskyi A. A. ta in. - K. : holov. red. URE,AN URSR, 1972. $816 \mathrm{~s}$.

4. Mativos, Yu. Dramatychna dolia dramatychnoho / Yu. Mativos // Kirovohradshchyna. Istoriia. Tradytsii. Suchasnist ; za zah. redaktsiieiu O. V. Chudnova. - Kirovohrad : ImeksLTD, 2008. - $640 \mathrm{~s}$.

5. Na pamyat o rodnom krae // Istoriya Tsentralnoy Ukrainyi / sost. A. Chudnov. - Kirovograd : Imeks-LTD, 2008. $432 \mathrm{~s}$.
6. Pamyatniki istorii i kulturyi Ukrainskoy SSR // Katalogspravochnik / P. T. Tronko [i dr.] ; AN USSR. — K. : Naukova dumka, 1987. - $736 \mathrm{~s}$.

7. Petrakov, V. V. Elisavetgrad v staroy otkryitke // «Malenkiy Parizh»/V. Petrakov. - M. : Pinakoteka, 2004. - 240 c.

8. Teatr v Kirovograde // Stroitelstvo i arhitektura. — 1979. — \# 1.

9. Teatr Marka Kropyvnytskoho // Mynule i suchasne. Albom. Avtor-uporiadnyk V.P.Shurapov. - Kirovohrad : PVTs «Mavik», 2004.

10. Tymofiienko, V. V. Zodchi Ukrainy kintsia KhIII — pochatku KhKh stolit // Biohrafichnyi dovidnyk / Volodymyr Tymofiienko. - K. : NDITIAM, 1999. - $476 \mathrm{~s}$.

11. TsDAVOVUU. - F. 4906. - Op. 1. - Spr. 1351.

12. Tam samo. - F. 2. - Op. 8.- Spr. 203.

13. DAKO. - F. R-6707.-- Od. zb. 53, 1838-1950 rr. Kirovohradskyi oblasnyi derzhavnyi arkhiv // Putivnyk. Kirovohrad, 1966.

14. Internet-resurs vid 16 bereznia $2005 \mathrm{r}$.

15. Internet-resurs vid 23 kvitnia $2009 \mathrm{r}$.

16. Internet-resurs vid 24 lystopada 2009 r.: www.informer.ua. 